\title{
Engaging with carbon markets: the Libya case
}

\author{
Sebastian Thomas ${ }^{1}$ and Paul Dargusch ${ }^{2}$ \\ University of Queensland, Australia
}

\section{Introduction}

This paper addresses the potential for engagement in international carbon markets by the Libyan Arab Jamahiriya (referred to throughout this paper as Libya). Specifically, the paper evaluates the extent to which Libya is likely to participate in the Clean Development Mechanism (CDM). The CDM is an example of integrated environmental and energy policy in that it seeks to achieve sustainability outcomes in developing countries while providing greenhouse gas emission reductions through emissions abatement or avoidance projects. This is a timely and important question, as Libya has recently been emerging from an extended period of isolation from the international community and seeking to address the very real environmental and economic concerns which affect its population (Bahgat 2010; St. John 2008; Zoubir 2009). The dramatic political upheavals of early 2011 imply that Libya will be faced with substantial challenges in terms of economic reconstruction and reorganisation, while at the same time requiring positive engagements with global markets and the international community at some future date, in order to rebuild its social systems and infrastructure.

Libya's history and socio-cultural conditions make it a unique and fertile subject for study (Scheffler 2003). The goal of the research presented here was to investigate whether Libya, a country with a "strongstate" tradition and ambitious socio-economic development plans, can achieve a successful balance between economy, society and ecology. This question has been discussed in the context of other states with similar characteristics (Adaman and Arsel 2008). More particularly, our purpose was to evaluate whether Libya is likely to engage successfully with the international carbon market through the CDM, in order to achieve economic, social and environmental sustainability outcomes. This paper offers a multidisciplinary perspective, considering historical factors and trends as well as the characteristics of Libyan society that influence strategic policy development and implementation.

It has been argued that the CDM does not independently allow countries to achieve their sustainable development objectives (Boyd et.al. 2009; Sutter and Parreño 2007). The CDM can, however, make positive contributions to development objectives (Olsen 2007). This paper adopts a political ecology approach to evaluate the likelihood of Libya being able to engage in the CDM for the purposes of reducing emissions and promoting sustainable development. Comprehensive understanding of these complex issues requires a political ecology method (Arvanitakis and Boydell 2010; Bumpus and Liverman 2008).

\section{Methods}

The political ecology approach applied in this paper comprises four aspects: (1) an examination of Libya's broader political economy; (2) an evaluation of the agency and governance of the CDM allowing for consideration of how these relate to Libyan circumstances; (3) the material dimensions of potential CDM activity in Libya; and (4) the discursive dimensions of this issue, in terms of achievable, realistic and probable development pathways and the role of government in encouraging particular activity types over others.

The research presented in this paper draws on three main sources. A review of literature in the fields of historical studies, sociology and contemporary energy policy was conducted to provide background and identify relevant factors for determining criteria for evaluation. Secondly, economic and demographic data was gathered for the analysis. Finally, discussion items from a workshop on CDM issues involving Libyan participants provided insights and information. The workshop was conducted in Tripoli by the authors in February 2010 as part of a capacity-building training course sponsored by the United Nations Development Program (UNDP).

These separate sources provided data that were evaluated according to CDM regulatory requirements, regional historical trends and economic decision criteria. The political ecology approach applied here allows for the identification of necessary and desirable factors for participation in CDM activities and incorporates social and economic considerations in these conditions. Libya's unique circumstances were

\footnotetext{
${ }^{1} \mathrm{PhD}$ candidate in the School of Business, University of Queensland, Level 5 Hartley Teakle Building, St Lucia QLD 4072, Australia. seth.thomas "at" uq.edu.au

${ }^{2}$ Lecturer in the School of Agriculture and Food Sciences, University of Queensland, Level 5 Hartley Teakle Building, St Lucia QLD 4072, Australia.
} 
applied to these criteria to determine opportunities for, and constraints on, the country's engagement with the global carbon market through CDM projects.

\section{Libya's political economy}

Libya (Fig. 1) is thought to have around 3.6\% of the world's oil reserves, with estimates ranging from 39 to 45 billion barrels (BMI 2009; Scott 2000; Taib 2009). The country's economy is largely dependent on hydrocarbons, which generate over 95\% of Libya's export income, and account for a quarter of Gross Domestic Product (GDP) (EIA 2010). The oil and gas sector also provides 60\% of public sector wages (CIA 2009). In the carbon-constrained economy of the 21st century, Libya's reliance on fossil fuel resources presents challenges and opportunities. While oil and gas represent major sources of secure revenue, non-fossil fuel sources will increasingly be preferred in the emerging global economy. In addition, restrictions imposed on carbon-intensive industries are likely to extend to all countries eventually, and with projected changes in the size, quality and accessibility of oil and gas fields, production costs are likely to rise, implying that revenue from the sector will diminish over time (Kjärstad and Johnsson 2009; Otman and Karlberg 2007). Finally, Libya's reliance on a one major economic sector makes it vulnerable to economic changes and limits the possibilities of entrepreneurship and trade in the country (St. John 2007; Otman and Karlberg 2007; Yousef 2004).

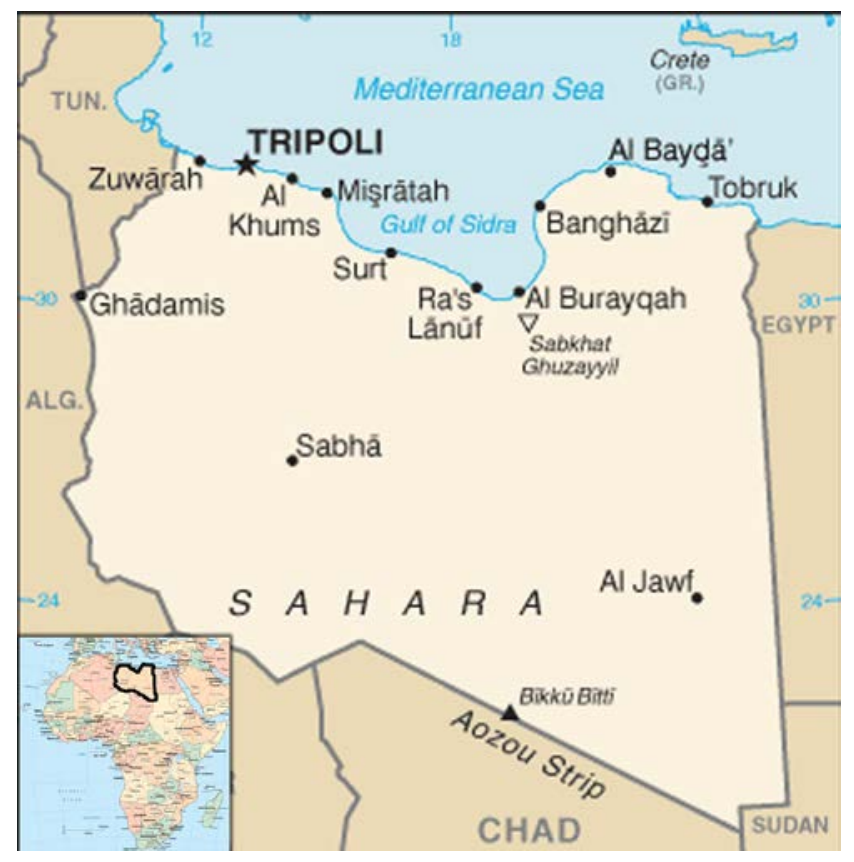

Fig. 1: Libya.

The army revolt against King Idris on 1 September 1969 established one of the world's most enduring and well-known regimes under the leadership of Colonel Muammar al-Qadhafi. During the 1970s and 1980s Libya's support of groups considered to be subversive or terrorist organisations by major world governments culminated with the imposition of United Nations (UN) sanctions in 1992. Libya became economically and politically isolated. Changes in Libya's policies, including admissions of involvement in terrorist actions and renunciation of certain weapon technologies, saw a gradual improvement in relations between Libya and the world community, resulting in the ending of UN sanctions in 2003 and a normalisation of relations with the United States (US) in 2006. Qadhafi has also pursued engagement with other African countries, and served as President of the African Union in 2009. He is recognised as a charismatic and often dramatic leader (St. John 2008). But the tenacity and severity of Qadhafi's regime has been demonstrated in the events of early 2011 when rebellion against his leadership was brutally surpressed. Qadhafi's military forces attacked civilian groups, and further evidence of repressive institutional practices has led, as of mid 2011, to a global vilification of his regime (Al Jazeera 2011).

Libya has experienced frequent political change over the last half century. In the 1950s it formed strategic partnerships with Britain and the United States, and at this time was one of the world's poorest countries with a literacy rate of around $10 \%$ (Zoubir 2009). At the end of the twentieth century, Libya was 
isolated from the international community and considered a sponsor of terrorism by numerous Western nations, yet had achieved one of the highest literacy rates in North Africa $-68.1 \%$ for women, $90.8 \%$ for men and 79.9\% overall (UNESCO 2006). Since 1950 urban populations in Libya have increased by two to three times. The abundance of oil and the lack of water and forest in the semi-arid regions and desert terrain have helped to accelerate this trend (Arimah and Ebohon 2000).

With rapid growth in urbanisation and immigration (in Libya's case largely from sub-Saharan Africa), cities are crowded, with a diverse younger population faced with inadequate housing, unemployment, and cultural or ethnic conflict (Otman and Karlberg 2007). Frustration with the lack of economic progress has been apparent in recent years, and there is a view that the Qadhafi regime benefits from abundant oil revenues yet fails to meet the basic needs of its people. This frustration was expressed in violent demonstrations in 2006 (Pargeter 2006), and there has been evidence of popular desire for change for some time, prior to open revolts against the regime in 2011.

Libya is a deeply religious society with a strong commitment to the Islamic system of economics and an abiding culture of community welfare. Qadhafi maintained a large bureaucracy structured to promote and protect government and national interests, although this is currently in disarray. Libya is fiercely proud of its hydrocarbon industry. Its energy policies are designed to avoid domination by foreign companies and it continues to distrust Western interests and non-Islamic cultures.

\section{Recent trends and characteristics}

It has been argued that resource-based economies with large centralised governments can no longer sustain competition against dynamic East Asian and central European economies, and there is considerable pressure on leaders to provide modern education with good labour market outcomes (Chaaban 2009). In Libya socio-economic and political reforms began (in a limited manner) in the late 1980 s, and continued in the 1990s, eventually removing or modifying virtually all of the fundamental principles of the 1969 army revolt, leaving intact only the original system of popular direct political involvement (St. John 2008). The remaining Libyan bureaucracy was characterised by an extensive number of committees, congresses, regulatory agencies and supervisory bodies, which serve to prevent any particular department or individual accruing any significant power (BMI 2010; St. John 2008). Ad hoc changes often occur, and increases in the number of Basic People's Congresses (the fundamental unit of Libya's participatory political system) to 30,000 in January 2006 may have been designed to absorb and occupy unemployed members of the public sector workforce. Government ministries have been created and dissolved with little or no notice, and there have been periods where there was no national department of health or education in operation (Pargeter 2006).

Major reforms to economic policy were announced in 2003 and 2004, although these were largely confined to the oil and gas sector. Privatisation of the hydrocarbon industry was not to be immediate but incremental, with the public and private sectors co-existing under ultimate government control. The hydrocarbon sector was to be the driver for wider economic development and diversification (St. John 2007). Economic forecasts for Libya remain positive, as long as there is continuing development of the country's hydrocarbon resources under whatever political regime survives the current crisis (BMI 2010). This positive sentiment comes after a long period of largely static economic activity. Libya's GDP, for instance, experienced little real growth during the 1980s and 1990s.

From 1969 to 2011 Libyan political leadership was constant, despite challenges by fundamentalist religious groups, and indications of rising popular discontent (St. John 2008; Pargeter 2006). In the last few years there have been indications that one of Qadhafi's sons, the western-trained Salif al-Islam Qadhafi, was being promoted to a position of authority, and some sectors - particularly the Western business community - saw this as a sign of potential economic liberalisation (BMI 2010). Libya's poor record on human rights was not generally an obstacle to engagement by European and international governments and companies up until recently (Lutterbeck 2009).

Matters changed in early 2011 with the widespread popular protest against the Qadhafi regime. The attempts of the Libyan people to enact regime change, supported by the United Nations and western powers, and the dramatic conflicts ongoing at the time of writing suggest that political reform is likely. It remains to be seen how Libya's socio-economic systems and institutions will alter in the near future, with or without the Qadhafi family at the helm.

\section{Social and cultural considerations}

Social development involves access to education and health services, and improvements in sanitation, human rights and political participation (e.g. Gold Standard Foundation 2008). In the Middle East and North Africa, social development by authoritarian regimes has been slow, and tends to be driven either by Islamic movements or non-government organisations (Bayat 2002). In Libya, both religious organisations and NGOs have been constrained by the state for a number of reasons. Islamic groups have been perceived as threatening the natural authority of the Jamahiriya (the country's unique political edifice) 
(Bayat 2002; St. John2008; Pargeter 2006), and international development organisations seeking to promote social advances and democratisation often appear to be concerned with electoral representation, legal or judicial development or support for liberal elements of civil society, and frequently undertake collection or distribution of information and support local pro-reform institutions (Carapico 2009). These types of activities have not been welcomed by the Libyan regime (BMI 2010).

The influence of religion on both public policy and popular participation in economic activities is important. Islamic tradition requires individuals to contribute $2.5 \%$ of their total income to fellow citizens, a tradition known as zaqat, and the socialist nature of the Jamahiriya state ensured that citizens were supported to some extent, although it is also thought that unemployment levels prior to the 2011 revolts were around 25-40\% (Pargeter 2006; Yousef 2004).

Critiques of Islamic economic principles point to the anachronistic nature of zaqat and the difficulties inherent in incorporating altruism (which is a key principle of Islamic economics) in market-based systems (Kuran 1986, 2004). Libya's fiscal regime currently includes the $2.5 \%$ tax on capital income, although this is an informal mechanism (Arebi 2010). There is an extensive welfare support system, although detailed data on employment statistics and fiscal policy can be difficult to obtain, and the extent of the application and integrity of this social support mechanism is uncertain.

Religious proscriptions on economic and entrepreneurial activity have always had immense influence on the development and character of commerce in societies (Penslar 2001; Richardson and McBride 2009). There are particular implications for economic risk management and investment analysis, although there are many examples of successful commercial partnerships between Islamic and non-Islamic companies and governments (Sundararajan and Errico 2002; Kuran 2004). Combined with other national and political factors, religious proscriptions in Libya have contributed to an unstable investment environment and slow economic development (BMI 2010; St. John 2007; Kuran 2004; Otman and Karlberg 2007; WBG 2009; Yousef 2004).

Until 2011 political reform in Libya has been constrained by the nature of the Jamahiriya bureaucracy. While there is an executive government structure in place, comprising the General People's Congress (the Parliament) and the General People's Committee (the Cabinet), its capacity to govern effectively was limited by the extensive informal power networks. These include the Basic People's Congresses (local political groups), Revolutionary Committees (extreme loyalists who control the Basic Congresses), Popular Social Leaderships and Social Youth Associations, and the network of informal advisors who occupy many positions of importance and have the ear of Qadhafi. Since relinquishing official titles he has been referred to by honorific titles such as "Brother Leader" (Pargeter 2006). This extensive and complex arrangement of politically active groups has meant that reformist initiatives have been limited in their social and spatial reach, and diluted in their impact. Furthermore employment practices, including non merit-based promotion, tend to militate against the growth and retention of good technical and professional expertise (El-Jardali et.al. 2009).

The development of CDM project activities requires an efficient and coordinated governance system, and these are not characteristics of the Jamahiriya bureaucracy. Optimal exploitation of oil and gas reserves in Libya will not occur unless chronic administrative and jurisdictional issues are resolved, and a long-term and coherent strategy is formulated (St. John 2007). While there are plentiful domestic oil and gas resources, effective management of these is necessary, and internal demand is constantly increasing. There is rapid growth in electricity demand based on domestic demographic trends (around 7\% per annum) and a previous expansion of the tourism sector. Libya's installed electricity generation capacity rose from 248 MW in 1970 to 2240 MW in 1980 and around 5000 GW by 2010. The General Electricity Company of Libya (GECOL) attempted to meet increased demand by doubling generation capacity between 2001 and 2010, and plans to double it again to a total of 10,000 MW in 2020. GECOL's existing operating deficit, however, is expected to increase as electricity prices have been heavily subsidised by the government. In order to achieve an economically sustainable power generation sector it has been argued that the Libyan government, if it survives, must restructure GECOL and eventually deregulate or privatise the sector entirely (Otman and Karlberg 2007).

\section{The Clean Development Mechanism}

The Clean Development Mechanism (CDM) was established by the Kyoto Protocol to the United Nations Framework Convention on Climate Change (UNFCCC), and is designed to provide cost-effective emission offsets for Annex 1 (industrialised) nations which have committed to emission reductions under the terms of the Protocol (UNFCCC 2009). The CDM operates by creating incentives for the implementation of projects in developing (non-Annex 1) countries, which reduce, avoid, destroy or sequester emissions that would otherwise have occurred. CDM projects can be of various types including energy efficiency, renewable energy production (such as wind, solar and hydroelectric power projects), methane utilisation or destruction, destruction of industrial gases, afforestation and reforestation, energy from biomass, landfill gas capture and fuel switching. The emission reductions from CDM projects earn 'carbon credits' (certified emission reductions or CERs) for each metric tonne of carbon dioxide 
equivalent $\left(\mathrm{tCO}_{2} \mathrm{e}\right)$ that is reduced or sequestered. CERs can be sold to firms in developed countries and then used by those firms to meet their emission reduction obligations under domestic legislation. CERs can also be traded as a commodity in international markets.

As well as verified emission reductions, CDM projects are required to demonstrate positive sustainable development outcomes, although the sustainability criteria are determined and evaluated by the host country rather than the UNFCCC. Host countries (developing - or 'non-Annex 1' - nations) wishing to participate in the CDM are required to establish a Designated National Authority (DNA), which is a government agency responsible for evaluation and registration of CDM projects, as well as the country's reporting in accordance with its Kyoto Protocol commitments.

The Asia-Pacific region presently hosts more than 75\% of the registered CDM projects, while Africa has less than $2 \%$ of the total, and the Middle East region just over 1\% (UNFCCC 2011). Interestingly, both Africa and the Asia-Pacific region have 52 non-Annex 1 Parties to the Kyoto Protocol, with 47 African Parties having established a DNA against 40 in the Asia-Pacific. However, there are only 57 registered CDM projects hosted by 19 African Parties, in contrast to the Asia-Pacific region where 2,365 projects are hosted by 27 countries (UNFCCC 2011). The uneven distribution of CDM activities globally is well-documented (Ellis, Winkler et.al. 2007). At the time of writing there were 19 CDM projects registered in both South Africa and Israel. Egypt hosted 7 projects, and Morocco and Nigeria had 5 each. There were 4 projects in the United Arab Emirates and 3 each in Uganda and Kenya. There were 2 projects in Tunisia, Syria, Senegal and Jordan. Zambia, Qatar, Iran, the Democratic Republic of the Congo, Mali, Mauritania, Tanzania, Ethiopia, Ivory Coast and Cameroon each hosted a single project (UNFCCC 2011). Libya ratified the UNFCCC in June 1999 and the Kyoto Protocol in August 2006 yet it hosts no CDM projects, and while the Libyan Environment General Authority was established as a DNA it has not yet provided the UNFCCC with the National Communications and other materials required by the Protocol (UNFCCC 2011).

While there has long been debate as to whether climate affects culture (Stehr 1996), it is indisputable that climate now affects economics. The speed and extent of the growth of carbon markets in the early 21st Century is testament to this fact. The carbon market has grown rapidly since its inception in the late 1990s, doubling transacted value from \$US63 billion in 2007 to more than \$US126 billion in 2008 (Capoor and Ambrosi 2009). With more than 2,000 projects registered to date, and around 4,000 in development, the CDM is the primary vehicle for Annex 1 countries to fulfil their Kyoto Protocol commitments to technology transfer to developing countries, and usually the most cost-effective means by which companies are able to meet abatement compliance obligations. The CDM has also increased the implementation of climate-friendly projects, raised awareness of climate change and mitigation strategies in developing countries, and augmented institutional capacity to develop and assess mitigation project opportunities (Ellis, Winkler et.al. 2007).

The use of offsets has been criticised as fundamentally inadequate in reducing global emissions (Bullock et.al. 2009), and there is evidence that the CDM has not achieved significant sustainable development outcomes (Boyd et.al. 2009; Olsen 2007). Global greenhouse gas emissions are continuing to increase, with emissions from fossil fuels estimated as being 40\% above 1990 levels in 2008 (Allison et.al. 2009). While the Kyoto Protocol commits Annex 1 countries to a combined reduction in their emissions of $5.2 \%$ on 1990 levels (UNFCCC 1998), non-Annex 1 countries like Libya are not yet required to make any reductions, despite rising emissions. It is clear, however, that all countries, developed and developing, will need to agree on reduction commitments if atmospheric greenhouse gas levels are to be stabilised and reduced (Boyd et.al. 2009; Garnaut 2008; Hansen et.al. 2008; Muller 2007; SCIO 2008). With further refinement and application, the CDM has potential to facilitate local sustainable development and emission reductions (Bumpus and Liverman 2008). The CDM can also help to motivate developing countries to accept future mitigation commitments (Ellis et.al. 2007).

\section{Material dimensions - perceived CDM opportunities and constraints}

The CDM is potentially a vehicle for attracting new foreign investment and technology transfer, for building institutions involved in climate change mitigation and adaptation, and for different types of public and private actors and entities to increase their awareness of technical and economic aspects of mitigation strategies (Ellis, Winkler et.al. 2007). But foreign direct investment (FDI) is more likely to flow to countries with stable governance conditions, strong legal and contractual environments, macroeconomic stability, a skilled workforce and institutional capacity (Georgiou et.al. 2008; Jung 2006; van der Gaast et.al. 2009). CDM projects mostly involve partnerships between companies in the host country and foreign firms that contribute funding, technology and expertise (Geels and Schot 2007; Lewis 2010). Foreign companies will not invest in CDM projects when the associated risk is too high, even though there may be potentially cheap emission reduction opportunities ('low-hanging fruit' project activities) for them (Muller 2007). It is possible for non-Annex 1 countries to implement unilateral CDM projects, but this requires the institutional capacity discussed previously. 
Evaluating the potential success of CDM projects in Libya requires consideration of the two objectives of the CDM: reducing carbon emissions and promoting sustainable development.

\section{Carbon emission reductions}

Certain CDM project types deliver attractive cost-benefit ratios in terms of certified emissions reductions, specifically hydrofluorocarbon (HFC) and nitrous oxide $\left(\mathrm{N}_{2} \mathrm{O}\right)$ elimination projects. In contrast, renewable energy and energy-efficiency systems often deliver higher-cost reductions but also higher long-term value in terms of the ability for project replication, local pollution reduction, technology transfer and sustainable development outcomes (Ellis, Winkler et.al. 2007; Figueres 2006; Schneider 2009; Sutter and Parreño 2007).

Libya's geography suggests opportunities exist for renewable energy projects, specifically solar and wind power electricity generation. Some research indicates that small-scale (village level) hybrid projects involving solar photovoltaic, wind and diesel combinations may be cost-effective even without CDM financing, and have the potential to significantly reduce emissions and contribute to local sustainable development outcomes (Gilau et.al. 2007). At larger scales there is considerable opportunity for technology transfer from European Union firms seeking to develop renewable energy projects (Karakosta et.al. 2010) and Europe in particular has a longstanding interest in the development of renewable energybased power generation in North Africa (Battaglini et.al. 2009). If large-scale renewable energy projects were implemented in Libya the country could also reduce its national carbon emissions.

Nonetheless Libya's potential as a host country for non-sink CDM projects (i.e. projects that do not involve carbon sequestration) was recently evaluated as "very unattractive" according to three criteria: mitigation potential, institutional capacity and the general investment climate (Jung 2006). This study excluded forestry activities because of their very different mitigation potentials and high levels of uncertainty (Jung 2005; Thomas et.al. 2010). Libya has also been assessed as being an unsuitable potential host country for CDM wind power projects, as investment costs and electricity tariffs are the decisive factors influencing economic return of projects (Georgiou et.al. 2008). These costs and tariffs are significant in Libya.

Libya's carbon emissions increased by 24\% from 1997 to 2007 (EIA 2010) and the country's estimated energy-related emissions in 2009 were estimated to be $55 \mathrm{M}$ tCO2e (EIA 2011). The dominance of fossil fuel energy sources implies that there is room for the development of renewable energy alternatives, but at the same time indicates that until a substantial shift occurs in energy provision its national emissions are unlikely to decline.

\section{Sustainable development}

As previously discussed, the CDM has been criticised for failing to achieve social and environmental sustainability outcomes (Bumpus and Cole 2010). Various suggestions have been made as to how to address this issue, including the possibility of rent extraction from CDM projects in the form of taxes on profits or revenue, or fixed fees, in order to provide revenue to support long-term national sustainability goals that are not addressed by CDM activities (Muller 2007). While imposed charges do affect investment analysis, it is possible for countries to successfully co-opt the CDM in order to further national development priorities (Thomas, Dargusch, and Griffiths 2011). Profit taxes can be differentiated according to project type (Liu 2008; Muller 2007), and fiscal structures imposed that encourage particular types of CDM activities (Ganapati and Liu 2008). The workshops conducted by the authors in Libya, described below, revealed that the issue of waste management and its impact on social and environmental conditions was a prominent concern of Libya's urban populace. Projects employing landfill gas capture are the largest component of the current CDM pipeline in countries of the Middle East and North Africa (MENA) and this is clearly an area of opportunity in Libya as well (Karakosta et.al. 2010).

Many of the arguments for reform of the CDM, whether they focus on rent extraction by project type (Liu 2008; Muller 2007) or mandatory sustainability criteria (Ellis, Baron et.al. 2007; Pinter et.al. 2005), presuppose that host country governments are concerned with long-term sustainability benefits. This may not be the case in Libya, although international observers have previously considered Saif al-Islam Qadhafi, to be more inclined toward both economic and political liberalisation if the regime survives (BMI 2010, 2010; St. John 2008; Otman and Karlberg 2007; Zoubir 2009). Reform actions have previously seemed to be mainly concerned with economic modernisation rather than social liberalisation (Pargeter 2006), but early 2011 has left the political situation confused and open. Even with a degree of economic reform, environmental problems may continue to worsen in terms of their scope, intensity and impact (Adaman and Arsel 2008).

We suggest that social and environmental sustainable development outcomes through CDM projects in Libya are most likely to occur either through small-scale projects at the village level, or in programmes of activities (POAs) in urban centres involving transport infrastructure or waste management. The CDM can be considered as a tool to implement sustainable development projects that would otherwise not be 
cost-effective. If Libya were able to fulfil the regulatory requirements of the CDM process, the state would have the opportunity to use the CDM to achieve its own development priorities and goals. However, despite repeated statements in recent years that it is seeking economic and structural reforms and attempting to combat corruption and ineffective governance the Libyan regime has done little more than make superficial, cosmetic changes which do not threaten the continuation of the status quo. This has contributed to increasing dissent within Libyan society, which Qadhafi's regime has systematically suppressed until now.

\section{Discursive dimensions of CDM activity in Libya}

As part of a UNDP-sponsored capacity-building program in "Climate Change and Carbon Management" (referred to hereafter as "the course") delivered in Tripoli (the Libyan capital), the authors conducted a series of informal workshops involving discussions focused on several key questions in February 2010. These included whether Libya was able to implement CDM projects and if so which types of projects were considered most beneficial for the Libyan government, the private sector and the Libyan people. The course was designed to help the participants understand the regulatory requirements of participation in CDM activities and encourage consideration of potential opportunities.

The workshops involved 22 participants - 20 employed by the Libyan Government (16 from the Libyan Environment General Authority and four from other government departments) and two held positions in the private firms engaged in oil and gas processing. The participants came to the course with different perspectives on climate change and carbon management, but all had some specific interest in the topic related to their employment. Most of the participants were concerned with specific environmental issues such as waste management, the development of alternative energy industries, coastal management, combating desertification, or the management of emissions in the transport or oil industry, and attended the course to find out more about the role of climate change and carbon management in dealing with these issues.

The course was conducted over five days and the workshop on CDM issues was convened over five hours on the fourth day. The authors designed and delivered the course and the workshops with the aim of introducing participants to the major issues associated with climate change and carbon management, particularly in regards to the principles and practices of engagement in the CDM. The course included a summary of climate change science, an introduction to international climate change mitigation policy, practicals on how to estimate greenhouse gas emissions from organisations, a review of emissions abatement options, methods for comparing the relative merits of different abatement options, an overview of energy efficiency and renewable energy technologies, and the organisational mechanics of conceptualising, evaluating and registering CDM projects. The social atmosphere in the course was congenial and relatively informal and participants enthusiastically engaged in discussion, particularly as the course progressed. The flow of discussion was occasionally constrained by language limitations (the authors do not speak Arabic) but those participants who had troubles articulating their views in English were assisted by a number of bilingual participants who had very high-level English language skills.

The workshop was framed primarily as a learning exercise in which the participants could deepen their understanding of the opportunities for CDM development and consider constraints. It was divided into two phases. In the first, participants formed four groups of between four and six members, and each group was asked to conceptualise a CDM project that they considered to be suitable for development in Libya. In the second phase all groups presented their results and discussed the issues they deemed likely to influence the development of each project, assuming that Libya were to establish a Designated National Authority to manage its Kyoto Protocol obligations and CDM activities. The authors acted as moderators in the discussion. There were five key questions: (1) what would be the main constraints on CDM project development in Libya; (2) who would be the most likely proponents of CDM projects in Libya; (3) what CDM project types are most likely to occur in Libya; (4) what project types would be most beneficial for Libya; and (5) who would benefit most from CDM projects in Libya - people and communities, businesses or government?

The results presented here are the authors' observations and interpretations of the discussion. The workshop was not presented as a data collection activity and participants did not engage in the workshop on the premise or with the understanding that they were supplying data. Participants were however pleased to assist the authors in promoting discussion about the scope for mitigation and sustainability projects in Libya.

\section{Workshop observations}

Despite some increased foreign investment in Libya since 1999 (mostly in the petroleum sector) the country continues to have high levels of poverty, inadequate and out-dated infrastructure, and a large yet inefficient bureaucracy (Pargeter 2006). Engineers in the Libyan construction industry have been assessed as being deficient in a number of areas, specifically communication skills, scientific, technical and legal 
knowledge, previous experience, knowledge and use of modern techniques, and their ability to respond effectively to logistics problems (Krima et.al. 2007).

Although the number of DNAs in African countries has grown since 2005 many are not yet operational (van der Gaast et.al. 2009). This characteristic was described in the workshops - participants stated that structures were in place (i.e. for managing UNFCCC compliance and reporting) but procedures did not yet exist. When asked to clarify this it was suggested that officers within the administrative system had been assigned responsibility but no resources or training had yet been provided.

A summary of the authors' observations of issues discussed by the participants during the workshop is provided in Table 1 . The issues are ranked in order of how prominently they featured in the discussion (the most prominent being at the top of each list).

\begin{tabular}{|c|c|}
\hline $\begin{array}{c}\text { 1. What would be the main constraints } \\
\text { on CDM project development? }\end{array}$ & $\begin{array}{c}\text { Technical requirements } \\
\text { Skilled staff }\end{array}$ \\
& $\begin{array}{c}\text { Transparency and cheating } \\
\text { Public awareness and conservatism (a reluctance to } \\
\text { pay taxes) } \\
\text { Lack of motivation }\end{array}$ \\
\hline $\begin{array}{c}\text { 2. Who would be the most likely } \\
\text { proponents of CDM projects in Libya? }\end{array}$ & $\begin{array}{c}\text { Combinations - international / domestic } \\
\text { Balance between government and private firms }\end{array}$ \\
\hline $\begin{array}{c}\text { 3. What project types are most likely to } \\
\text { occur in Libya? }\end{array}$ & $\begin{array}{c}\text { Solar } \\
\text { Waste }\end{array}$ \\
$\begin{array}{c}\text { 4. What project types would be most } \\
\text { beneficial for Libya? }\end{array}$ & $\begin{array}{c}\text { Gas capture and flaring } \\
\text { All sectors }\end{array}$ \\
& $\begin{array}{c}\text { Government will direct project development to the } \\
\text { petroleum sector }\end{array}$ \\
\hline $\begin{array}{c}\text { 5. Who would benefit most from CDM } \\
\text { projects - people and communities, } \\
\text { businesses or government? }\end{array}$ & $\begin{array}{c}\text { Waste management projects } \\
\text { Alternative energies } \\
\text { Oil and gas retrofitting }\end{array}$ \\
\hline
\end{tabular}

Table 1: Workshop responses to questions about Libya's potential engagement with the CDM (2010)

Afforestation and reforestation projects were not perceived as feasible, although there was interest in this area as a potential strategy for combating desertification. Waste management was viewed as a major priority for sustainable development in Libya, and thus landfill gas capture and flaring CDM projects were considered desirable. Water supply was recognised as an issue of importance but workshop participants implied it was under control. Interestingly, despite the size of Libya's oil and gas industries, and the commensurate opportunities for fuel switching, energy efficiency and methane capture projects, workshop participants were more interested in social and environmental outcomes derived from CDM projects than in reform of the petroleum sector. Participants were enthusiastic about the possibilities represented by the CDM in terms of economic benefit, international engagement and local sustainable development outcomes. Most participants considered waste management and desertification as the most significant concerns for Libyan society, and renewable energy projects as the most interesting and attractive CDM opportunities but they were unclear as to how the necessary administrative changes could be made to effect project implementation.

\section{Conclusion}

New forces, circumstances and issues are affecting the lives and futures of people in the Middle East and North Africa, and public policy in the region must consider these forces as leaders choose strategic paths toward the future (Chaaban 2009). Employment growth in the private sector outside of the oil and gas industry is considered to be the only solution to increasing unemployment and low wages in MENA countries, since the public sector is likely to be unable to absorb a growing youth labour pool and community of graduates, and the hydrocarbon industry is capital-intensive and operates a relatively small 
workforce (Yousef 2004). The CDM represents an opportunity to encourage emission reduction and sustainable development activities not only in the hydrocarbon sector but in other priority areas including waste management and renewable energy generation.

Libya is currently facing a major political crisis and it is doubtful that CDM projects will advance until governance is restored and relations re-established with western countries. While there would seem to be considerable opportunities for CDM project activities in Libya including landfill gas capture, energy efficiency, methane avoidance and destruction, and renewable energies (particularly wind and solar), it is also clear that CDM project development is constrained by the lack of institutional capacity and a stable investment environment.

It is possible that economic reforms could be implemented without the hoped-for political liberalisation taking place. In China, for instance, economic reforms instituted from the late 1970s involved the creation of a private sector and competitive market institutions without political liberalisation. This involved a policy framework in which the state regulates the market and the market guides commercial enterprises, allowing the ruling Communist Party to maintain political control while individuals benefited from increased prosperity and rising standards of living. The success of this limited liberalisation has been attributed to three key elements of the state's policy: encouragement of material incentives and profit, openness to foreign investment and technology transfer, and the allowance of nonuniform development within the country (meaning that sectors and regions could progress at different rates) (Hsiung 2009). It seems likely that Libya could meet the second and third of these criteria, but the Jamahiriya state has demonstrated its inability to condone a relaxation of state controls.

The political ecology of Libya's potential engagement in carbon markets through the CDM is complex, and considerable uncertainties remain about the country's future governance. In view of the social and economic challenges discussed in this paper, and the opportunities represented by the CDM, it appears that while Libya could benefit considerably from implementation of CDM projects it is at present unable to pursue project development. In the longer term the CDM could contribute to a broad range of development outcomes, and the political liberalisation and economic reforms necessary to operate the CDM are seen in the Middle East as an effective path to achieving social stability (Yousef 2004). CDM project activities could be utilised to facilitate economic recovery, sustainable development, technology transfer, capacity building and Libya's engagement with the international community in the period following the upheavals of early 2011.

In order to effectively engage with the CDM, Libya must fulfil certain minimum conditions. These include the establishment of a DNA to administer CDM activities, and the implementation of economic and fiscal policies which will drive investment in CDM projects by foreign firms and project development by domestic organisations and companies. The Environment General Authority has been established as Libya's DNA, but the country's UNFCCC obligations remain unfulfilled. Specifically, Libya has not yet lodged an initial National Communication on the steps it is taking to implement the UNFCCC. Libya will also need improved institutional capacity, which includes broad technical competence in CDM project requirements and related areas, as well as transparency and stability of governance. Without these, Libya is unlikely to be able to attract the interest of foreign investors seeking CDM project development opportunities, as the CDM registration process is highly regulated and complex. Investors will not participate in project activities if there is uncertainty over the host party's ability to effectively manage the regulatory requirements. The lack of technical and institutional capacity further implies that unilateral CDM projects are unlikely to be successful. There is a clear need for international support and capacity building programs around all these issues.

Libya is endowed with natural resources that make renewable energy projects feasible. There is potential for investment in large-scale projects that would provide a range of economic benefits including employment and education opportunities. There is also potential for project development in the areas of waste management and transport infrastructure. However, the nature of the country's political system and economic structures, its inconsistent policy history, uncertain governance and its reliance on the hydrocarbon sector imply that successful engagement will be difficult at best.

Prospects for CDM project development in the foreseeable future are poor if the Qadhafi regime endures, given rapidly diminished trust in the regime. If the current civil conflict results in positive regime change, the international community should consider the CDM as a potentially valuable component of Libya's reconstruction and development strategy. The goals of the UNFCCC, including emission reductions, institutional capacity building and technical development, can be facilitated through CDM activities, and the CDM could also be employed as one mechanism to support the people of Libya in the future. 


\section{References}

Adaman, F., and M. Arsel. 2008. The European Union and Turkey: who defines environmental progress? International Journal of Middle East Studies 40: 541-543.

Al Jazeera. 2011. Evidence of Libya torture emerges. Al Jazeera English [accessed March 302011 ]. Available at http://english.aljazeera.net/video/africa/2011/03/20113122102545671.html

Allison, I., N. Bindoff, P. Cox, N. de Noblet, M. England, J. Francise, N. Gruber, A. Haywood, D. Karoly, G. Kaser, C. Le Quere, T. Lenton, M. Mann, B. McNeil, A. Pitman, S. Rahmstorf, E. Rignot, H. Schellnhuber, S. Schneider, S. Sherwood, R. Somerville, K. Steffen, E. Steig, M. Visbeck, and A. Weaver. 2009. The Copenhagen Diagnosis: updating the world on the latest climate science. Sydney: The University of New South Wales Climate Change Research Centre.

Arebi, M. 2010. Personal communication to the author regarding Libyan taxation. Tripoli, March 20, 2010.

Arimah, B. C., and O. J. Ebohon. 2000. Energy transition and its implications for environmentally sustainable development in Africa. International Journal of Sustainable Development \& World Ecology 7: 201-216.

Arvanitakis, J. and S. Boydell. 2010. The Miner and the Activist: a parable for our carbon constrained world. Journal of Political Ecology 17: 59-67.

Bahgat, G. 2010. The geopolitics of energy: Europe and North Africa. The Journal of North African Studies 15: 39-49.

Battaglini, A., J. Lilliestam, A. Haas, and A. Patt. 2009. Development of SuperSmart Grids for a more efficient utilisation of electricity from renewable sources. Journal of Cleaner Production 17: 911918.

Bayat, A. 2002. Activism and social development in the Middle East. International Journal of Middle East Studies 34: 1-28.

BMI. 2009. North Africa: exports to lead recovery in 2010. Business Monitor International.

BMI. 2010. Business outlook: Libya. Business Middle East 18: 11.

BMI. 2010. Government functions. Libya Country Review: 27-29.

BMI. 2010. Human rights event a sign of change. Africa Monitor: North Africa Monitor 15: 6.

BMI. 2010. Libya: risk summary. Africa Monitor: North Africa Monitor 15: 5.

Boyd, E., N. Hultman, J. Timmons Roberts, E. Corbera, J. Cole, A. Bozmoski, J. Ebeling, R. Tippman, P. Mann, K. Brown, and D.M. Liverman. 2009. Reforming the CDM for sustainable development: lessons learned and policy futures. Environmental Science and Policy 12: 820-831.

Bullock, S., M. Childs, and T. Picken. 2009. A dangerous distraction: why offsetting is failing the climate and people. London: Friends of the Earth.

Bumpus A.G. and Liverman D.M. 2008. Accumulation by decarbonisation and the governance of carbon offsets. Economic Geography 84 (2): 127-156.

Bumpus, A.G. and J.C. Cole. 2010. How can the current CDM deliver sustainable development? Wiley Interdisciplinary Reviews: Climate Change 1(4): 541-547.

Capoor, K., and P. Ambrosi. 2009. State and trends of the carbon market 2009. Washington, D.C.: The World Bank.

Carapico, S. 2009. What does it mean, 'promoting democratization'? International Journal of Middle East Studies 41: 7-9.

Chaaban, J. 2009. Youth and development in the Arab Countries: the need for a different approach. Middle Eastern Studies 45: 33-55.

CIA. 2009. CIA World Factbook. US Central Intelligence Agency. Available at https://www.cia.gov/library/publications/the-world-factbook/

EIA. 2010. Country Information. US Department of Energy Environmental Information Administration. [accessed March 2 2010]. Available at www.eia.doe.gov

EIA. 2011. Country Analysis Brief: Libya. US Department of Energy Environmental Information Administration. [accessed March 30 2010]. Available at http://www.eia.doe.gov/emeu/cabs/Libya/pdf.pdf

El-Jardali, F., V. Tchaghchagian, and D. Jamal. 2009. Assessment of human resources management practices in Lebanese hospitals. Human Resources and Health 7: 84.

Ellis, J., R. Baron, and B. Buchner. 2007. SD-PAMs: what, where and when and how? Paris: International Energy Agency. 
Ellis, J., H. Winkler, J. Corfee-Morlot, and F. Gagnon-Lebrun. 2007. CDM: taking stock and looking forward. Energy Policy 35: 15-28.

Figueres, C. 2006. Sectoral CDM: Opening the CDM to the yet unrealized goal of sustainable development. International Journal of Sustainable Development Law \& Policy 2: 5-26.

Gold Standard Foundation. 2008. The Gold Standard. Geneva: Gold Standard Foundation.

Ganapati, S., and L. Liu. 2008. The Clean Development Mechanism in China and India: a comparative analysis. Public Administration and Development 28: 351-362.

Garnaut, R. 2008. The Garnaut Climate Change Review: final report. Australian Government, Department of Climate Change.

Geels, F. W., and J. Schot. 2007. Typology of sociotechnical transition pathways. Research Policy 36: 399-417.

Georgiou, P., C. Tourkolias, and D. Diakoulaki. 2008. A roadmap for selecting host countries of wind energy projects in the framework of the Clean Development Mechanism. Renewable and Sustainable Energy Reviews 12: 712-731.

Gilau, A. M., R. Van Buskirk, and M. J. Small. 2007. Enabling optimal energy options under the Clean Development Mechanism. Energy Policy 35: 5526-5534.

Hansen, J., M. Sato, P. Kharecha, D. Beerling, R. Berner, V. Masson-Delmotte, M. Pagani, M. Raymo, D. L. Royer, and J. C. Zachos. 2008. Target atmospheric $\mathrm{CO}_{2}$ : where should humanity aim? The Open Atmospheric Science Journal 2: 217-231.

Hasso, F. S. 2009. Empowering governmentalities rather than women: The Arab Human Development Report 2005 and Western development logics. International Journal of Middle East Studies 41: 6382.

Hsiung, J. 2009. From revolutionary regime to normal governance: China's long march toward political reform. Asian Affairs: an American Review 36 (1): 29-46.

St. John, R.B. 2007. Libya's oil and gas industry: blending old and new. The Journal of North African Studies 12: 203-218.

St. John, R.B. 2008. Redefining the Libyan revolution: the changing ideology of Muammar al-Qadhafi. The Journal of North African Studies 13 (1):91-106.

Jung, M. 2005. The role of forestry projects in the Clean Development Mechanism. Environmental Science and Policy 8: 87-104.

Jung. 2006. Host country attractiveness for CDM non-sink projects. Energy Policy 34: 2173-2184.

Karakosta, C., H. Doukas, and P. John. 2010. EU-MENA energy technology transfer under the CDM: Israel as a frontrunner? Energy Policy 38 (5): 2455-2462.

Kjärstad, J., and F. Johnsson. 2009. Resources and future supply of oil. Energy Policy 37: 441-464.

Krima, N. A., G. Wood, G. F. Aouad, and Z. Hatush. 2007. Assessing the performance of Libyan supervising engineers. Construction Management and Economics 25: 509-518.

Kuran, T. 1986. The economic system in contemporary Islamic thought: interpretation and assessment. International Journal of Middle East Studies 18: 135-164.

Kuran. 2004. Why the Middle East is economically underdeveloped: historical mechanisms of institutional stagnation. The Journal of Economic Perspectives 18: 71-90.

Lewis, J. I. 2010. The evolving role of carbon finance in promoting renewable energy development in China. Energy Policy 38 (6): 2875-2886.

Liu, X. 2008. Rent extraction with a type-by-type scheme: an instrument to incorporate sustainable development into the CDM. Energy Policy 36: 1873-1878.

Lutterbeck, D. 2009. Migrants, weapons and oil: Europe and Libya after the sanctions. The Journal of North African Studies 14: 169 - 184.

Muller, A. 2007. How to make the Clean Development Mechanism sustainable: the potential of rent extraction. Energy Policy 35: 3203-3212.

Olsen, K.H. 2007. The Clean Development Mechanism's contribution to sustainable development: a review of the literature. Climatic Change 84: 59-73.

Otman, W., and E. Karlberg. 2007. The Libyan economy: economic diversification and international repositioning. Berlin: Springer.

Pargeter, A. 2006. Libya: Reforming the impossible? Review of African Political Economy 33: 219-235.

Penslar, D. 2001. Shylock's children: economics and Jewish identity in modern Europe. Berkeley: University of California Press. 
Pinter, L., P. Hardi, and P. Bartelmus. 2005. Sustainable development indicators: proposals for a way forward. New York: United Nations Division for Sustainable Development.

Richardson, G., and M. McBride. 2009. Religion, longevity, and cooperation: the case of the craft guild. Journal of Economic Behavior and Organization 71: 172-186.

Scheffler, T. 2003. 'Fertile Crescent', 'Orient', 'Middle East': The Changing Mental Maps of Southwest Asia. European Review of History 10: 253-272.

Schneider, L. 2009. Assessing the additionality of CDM projects: practical experiences and lessons learned. Climate Policy 9: 242-254.

SCIO. 2008. China's policies and actions for addressing climate change. White Paper. Beijing: Information Office of the State Council of the People's Republic of China. Available at http://www.china.org.cn/government/whitepaper/node_7055612.htm

Scott, N. 2000. Mining Annual Review 2000: Libya. Paper read at African Mining 2000 Investment and Business Opportunities symposium. Burkina Faso, Ouagadougou.

Stehr, N. 1996. The ubiquity of nature: climate and culture. Journal of the History of the Behavioral Sciences 32: 151-159.

Sundararajan, V., and L. Errico. 2002. Islamic financial institutions and products in the global financial system: key issues in risk management and challenges ahead. International Monetary Fund Working Paper 02/192.

Sutter, C., and J. Parreño. 2007. Does the current Clean Development Mechanism (CDM) deliver its sustainable development claim? An analysis of officially registered CDM projects. Climatic Change 84: 75-90.

Taib, M. 2009. The mineral industry of Libya. In 2007 Minerals Yearbook: U.S. Geological Survey, U.S. Department of the Interior.

Thomas, S., P. Dargusch, and A. Griffiths. 2011. The drivers and outcomes of the Clean Development Mechanism in China. Environmental Policy and Governance, in press.

Thomas, S., P. Dargusch, S. Harrison, and J. Herbohn. 2010. Why are there so few afforestation and reforestation Clean Development Mechanism projects? Land Use Policy 27: 880-887.

UNESCO. 2006. Global Education Digest 2006. Montreal: UNESCO Institute for Statistics.

UNFCCC. 1998. Kyoto Protocol to the United Nations Framework Convention on Climate Change. Kyoto, Japan: United Nations.

UNFCCC. 2011. Clean Development Mechanism Projects Website. United Nations Framework Convention on Climate Change [accessed March 30 2011]. http://www.cdm.unfccc.int

van der Gaast, W., K. Begg, and A. Flamos. 2009. Promoting sustainable energy technology transfers to developing countries through the CDM. Applied Energy 86: 230-236.

WBG. 2009. Libya at a glance. Washington DC: The World Bank.

Yousef, T. M. 2004. Development, growth and policy reform in the Middle East and North Africa since 1950. The Journal of Economic Perspectives 18: 91-115.

Zoubir, Y. H. 2009. Libya and Europe: economic realism at the rescue of the Qaddafi authoritarian regime. Journal of Contemporary European Studies 17: 401-415. 


\begin{abstract}
Climate change and the emerging carbon-constrained economy of the 21st Century present new challenges and opportunities for countries of the Middle East and North Africa. This paper discusses the potential for Libya to participate in the Clean Development Mechanism (CDM), the main flexibility mechanism of the Kyoto Protocol, which is designed to reduce greenhouse gas emissions and promote sustainable development. The paper considers the interaction of Libya's history and socio-cultural characteristics with global policy dynamics and economic forces. Libya's geography presents considerable potential in terms of CDM project opportunities, yet key developments would be required before these could be exploited. The nature of Libya's political system and social structures suggest that these developments are unlikely to occur while the Qadhafi regime endures, and therefore that Libya will not be able to engage successfully with the CDM and international mitigation activities in the short term. However, the CDM represents a means to implement capacity building and technical development programs, which will be integral components of reconstruction strategy in the aftermath of the dramatic events of early 2011.
\end{abstract}

Keywords: Libyan energy policy; Clean Development Mechanism; political ecology; socio-economic reform; Kyoto Protocol.

\title{
Résumé
}

Le changement climatique et le «carbon-constrained economy» du 21ème siècle présente quelques nouveaux défis et opportunités pour les pays du Moyen-Orient et de l'Afrique du Nord. Cet article examine le potentiel de la Libye à participer au Mécanisme de Développement Propre (MDP), le principal mécanisme de flexibilité du Protocole de Kyoto, qui vise à réduire les émissions de $\mathrm{CO}_{2}$ et de promouvoir le développement durable. L'article examine l'interaction de l'histoire de la Libye et sa caractéristiques socio-culturelles avec la dynamique politique globale et les forces économiques. Les conditions géographiques de la Libye présente un potentiel considérable en termes de possibilités de projets MDP, mais les développements clés seraient nécessaires avant que ceux-ci pourraient être exploitées. La nature du système politique de la Libye et les structures sociales donnent à penser que ces évolutions ne sont pas susceptibles de se produire pendant la durée du régime de Kadhafi, et donc que la Libye ne sera pas en mesure d'engager avec succès les activités d'atténuation du MDP et internationaux à court terme. Toutefois, le MDP est un moyen de mettre en œuvre le renforcement des capacités et programmes de développement technique, qui sera partie intégrante de la stratégie de reconstruction à la suite des événements dramatiques du début de 2011.

Mots-clés: Politique énergétique de la Libye; Mécanisme de Développement Propre, l'écologie politique, la réforme socio-économique; Protocole de Kyoto; MDP.

\section{Resumen}

El cambio climático y el «carbon-constrained economy» limitada del siglo 21 presentan nuevos desafíos y oportunidades para los países de Oriente Medio y África del Norte. En este trabajo se analiza la posibilidad de que Libia a participar en el Mecanismo para un Desarrollo Limpio (MDL), el principal mecanismo de flexibilidad del Protocolo de Kyoto, que está diseñado para reducir las emisiones de $\mathrm{CO}_{2} \mathrm{y}$ promover el desarrollo sostenible. En el documento se considera la interacción de la historia de Libia y las características socio-culturales con la dinámica de la política mundial y las fuerzas económicas. Geografía de Libia presenta un potencial considerable en términos de oportunidades de proyectos MDL, sin embargo, los principales acontecimientos que se requiere antes de que estos podrían ser explotados. La naturaleza del sistema político de Libia y las estructuras sociales sugieren que estos acontecimientos es poco probable que ocurra mientras que el régimen de Gadafi perdura, y por lo tanto que Libia no podrá participar con éxito en las actividades de mitigación del MDL e internacional en el corto plazo. Sin embargo, el MDL representa un medio para poner en práctica la creación de capacidades y programas de desarrollo técnico, que será parte integrante de la estrategia de reconstrucción a raíz de los dramáticos acontecimientos de principios de 2011.

Palabras clave: La política energética de Libia; Mecanismo para un Desarrollo Limpio, la ecología política, la reforma socio-económica; Protocolo de Kyoto. 